\title{
EARLY DIAGENETIC CHALCOPYRITE OCCURRENCES IN TELYCHIAN MARINE RED BEDS OF WEST ESTONIA AND WEST LATVIA
}

\author{
Enli KIIPLI ${ }^{\mathrm{a}}$, Tarmo KIIPLI ${ }^{\mathrm{b}}$, and Toivo KALLASTE ${ }^{\mathrm{a}}$
}

\author{
a Institute of Geology, Tallinn Technical University, Estonia pst. 7, 10143 Tallinn, Estonia; \\ ptrgi@teleport.ee \\ ${ }^{\mathrm{b}}$ Mining Institute of Tallinn Technical University, Kopli 82, 10412 Tallinn, Estonia
}

Received 9 March 2000, in revised form 6 June 2000

\begin{abstract}
In the Telychian (Lower Silurian) marine red beds of the Aizpute core (West Latvia) and several cores of Saaremaa Island (West Estonia) chalcopyrite crystals up to $0.5 \mathrm{~mm}$ in size were found in thin red and grey altered volcanic ash layers and in red and yellow terrigenous claystones and marls. The control of sedimentary facies on the distribution of chalcopyrite suggests its formation in early diagenesis. Chalcopyrite finds are more frequent in metabentonites than in terrigenous rocks, presumably due to better $\mathrm{Cu}$-adsorbing properties of the authigenic clay, and amorphous ferric and supposedly once existent but not preserved by the present time manganese oxides. In the West Latvian Aizpute core the findings of chalcopyrite are more numerous and $\mathrm{Cu}$ contents are higher than in Saaremaa sections. Correlation of three metabentonite layers in the Aizpute core and the Viki core of Saaremaa hints at earlier onset of red bed facies in the Aizpute area.
\end{abstract}

Key words: chalcopyrite, marine red bed facies, metabentonite correlation.

\section{INTRODUCTION}

The sedimentary sulphide mineralization is rare in red hematitic rocks. Investigation of the Lower Silurian (Telychian) red beds of deep shelf facies in the Aizpute drill core of West Latvia and several cores of West Estonia (Fig. 1) revealed the occurrence of chalcopyrite in the form of small, up to $0.5 \mathrm{~mm}$ size tetrahedral crystals (Photo 1a,b) in red and grey altered volcanic ash layers metabentonites (MBs) and in red and yellow terrigenous claystones and marls. Previous records of chalcopyrite occurrence in Estonia refer to its hydrothermal or unknown genesis (Pirrus 1962, 1973; Kuuspalu \& Vanamb 1975). The aim of the present paper is to identify chalcopyrite occurrence, follow its distribution in red facies, and to characterize the host rock with implication to chalcopyrite genesis. The correlation of MBs from West Latvia and Saaremaa enables us to compare the sedimentation rates in shoreward and offshore parts of the deep shelf 


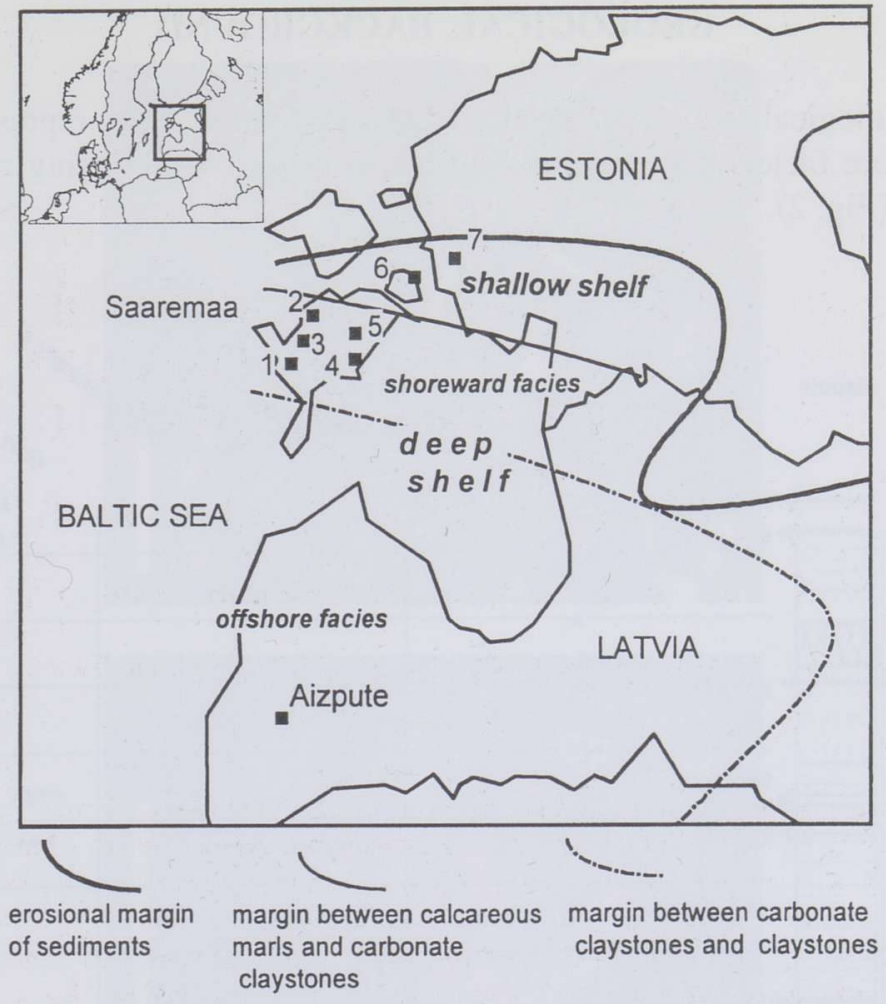
1, Viki
2, Pahapilli
3, Mustjala
4, Nässumaa
5, Valjala
6 , Löetsa 7 , Kirikuküla

Fig. 1. Location of boreholes and main facies margins in the Telychian (Lower Silurian). Modified after Kaljo (1977, fig. 2).

facies and follow the red facies onset and movement in time and space. Sedimenthosted stratiform ore deposits of copper are known from many regions (Gustafson \& Williams 1981). Considering the similarity of $\mathrm{Cu}$ behaviour in the oxic sedimentary environment of present oceans and ancient seas, implications to recent processes are reliable. Many authors have studied geochemistry of $\mathrm{Cu}$ in modern marine environments and sediments. Boyle et al. (1977) discuss the distribution of dissolved copper in the water column of the Pacific Ocean; Callender \& Bowser (1980) investigated the $\mathrm{Cu}$ content in interstitial fluids of oceanic bottom sediments; Chester et al. (1988) studied the $\mathrm{Cu}$ speciation in oceanic sediments; Piper \& Isaacs (1995) point out the importance of plankton as a source of $\mathrm{Cu}$; adsorbtion of $\mathrm{Cu}$ on modern $\mathrm{Fe}-\mathrm{Mn}$ crusts has been studied by Koschinsky \& Halbach (1995), Novikov \& Skornyakova (1998), Dubinin (1998), and in Jurassic crusts by Jimenez-Espinoza et al. (1997). Rose (1976) deals with solubility of $\mathrm{Cu}$; reduction spheroids in red beds of Proterozoic to Cenozoic age are described by Hofmann (1991). 


\section{GEOLOGICAL BACKGROUND}

The lithological section of the West Latvian Aizpute core, representing deep shelf offshore facies of the Lower Silurian, consists of alternating red and grey claystones (Fig. 2).

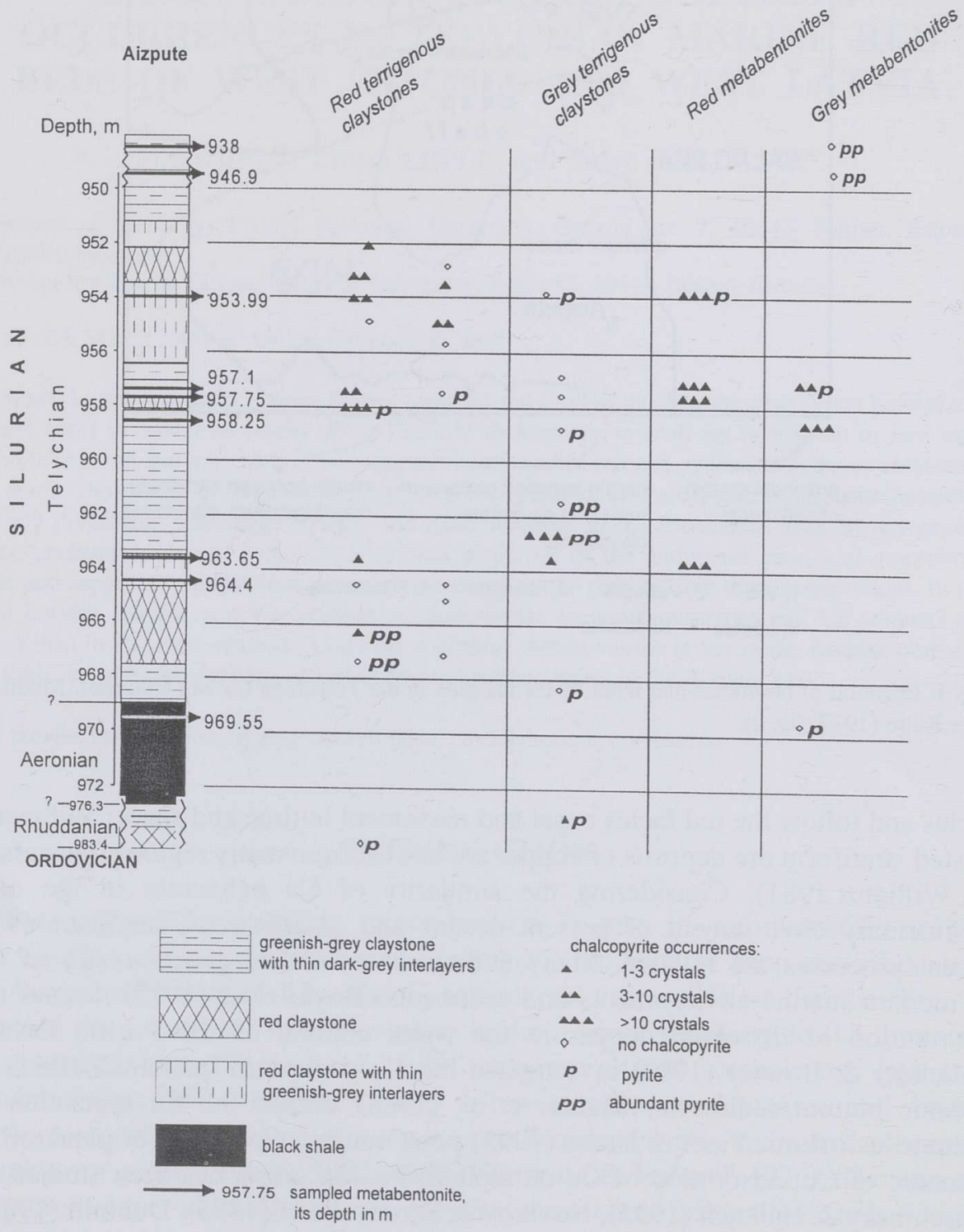

Fig. 2. Chalcopyrite finds in the Lower Silurian section of the Aizpute core. 

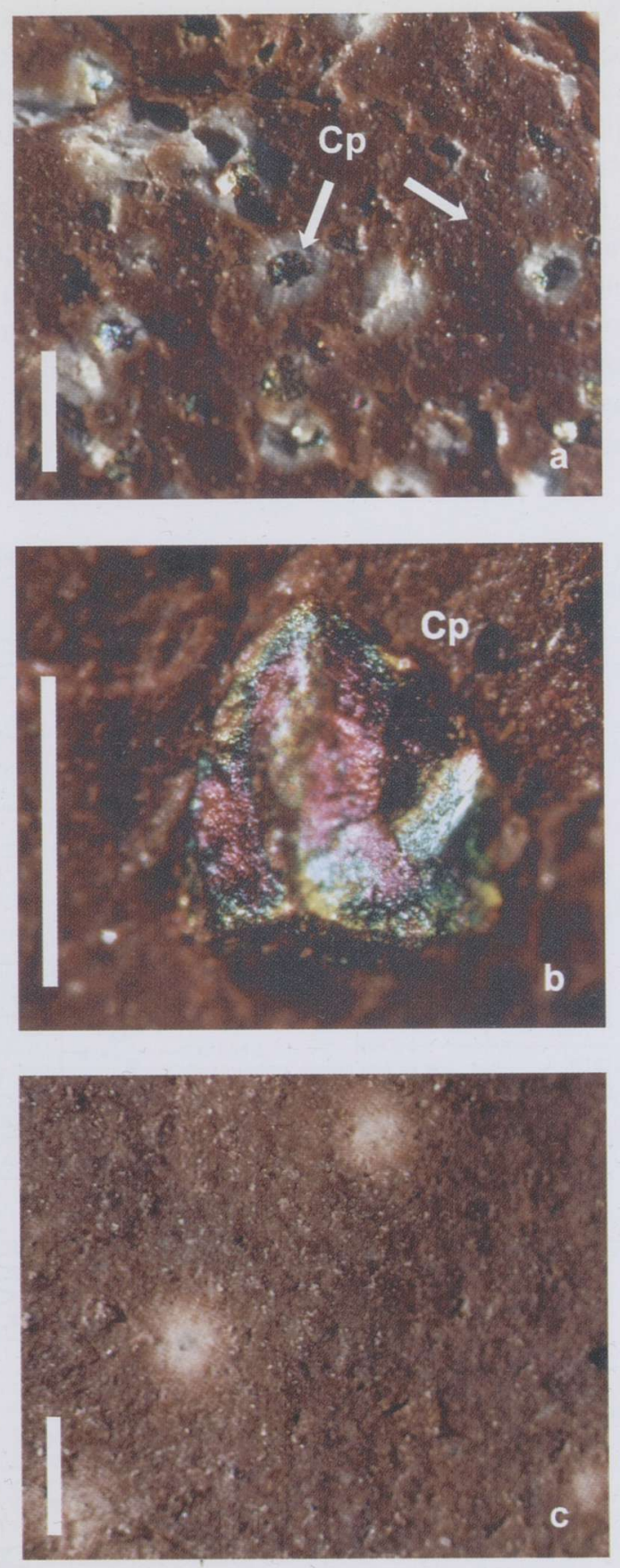

Photo 1. (a) Chalcopyrite crystals on the red hematitic metabentonite layer surrounded by bleached haloes, sample A957.1. (b) Chalcopyrite crystal within red hematitic matrix, sample A953.99. (c) Bleached spots within red metabentonite, sample Vi173.1. Scale bars $=0.5 \mathrm{~mm}$. 

The sampled intervals of cores from deep shelf shoreward facies of Saaremaa Island (West Estonia) are represented mainly by claystones, often dolomitic, and marls. Red Telychian intervals are thicker in western and southern Saaremaa, for example in the Viki (Fig. 3), Mustjala, and Nässumaa cores, thinning and disappearing north- and eastwards. In the Pahapilli and Valjala cores red and yellow layers are rare; red layers are mainly MBs. Rocks of the Jaani Formation are grey in all Saaremaa cores. The interval considered in the present paper corresponds to the Velise Formation of Telychian age (Nestor 1997). A detailed palaeontological description of this interval is available in Jeppsson \& Männik (1993). Approximately the same stratigraphic level (Telychian) was studied in the Aizpute core. The lower part of the Telychian in Aizpute and Saaremaa is correlated based on altered volcanic ash beds in these sections, namely on pyroclastic sanidine composition and immobile trace elements $\mathrm{Nb}, \mathrm{Zr}, \mathrm{Y}$, Ti (Table 1).

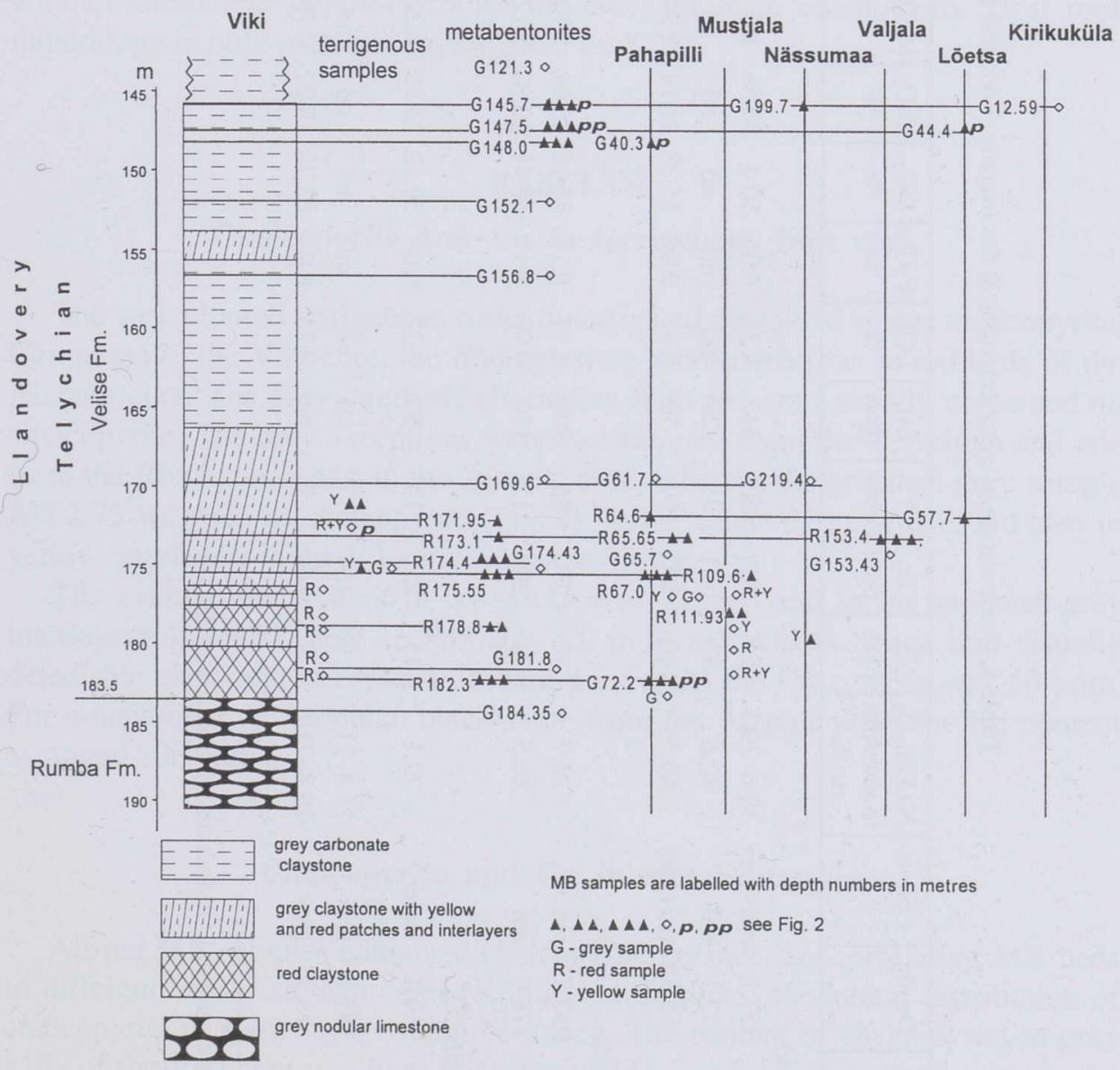

Fig. 3. Chalcopyrite finds in the Lower Silurian of West Estonian cores. 


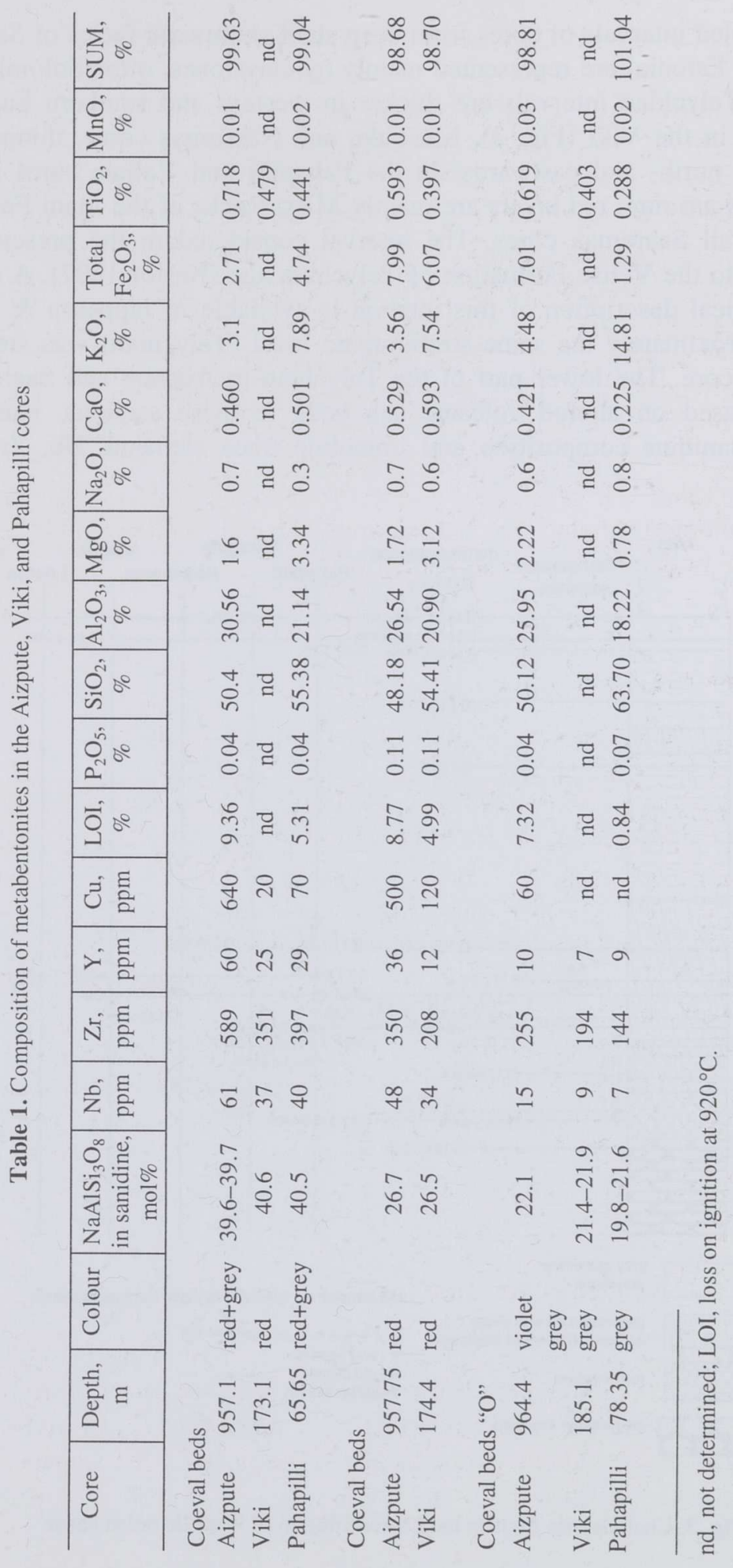




\section{SAMPLES AND STUDY METHODS}

A total of 102 samples from alternating red and grey beds - terrigenous rocks and $\mathrm{MBs}$ - were investigated for chalcopyrite. In part samples previously analysed for hematite and goethite (Kiipli et al. 2000) were used. The samples were suspended ultrasonically, after that the liquid was poured away. Chalcopyrite crystals were identified under the binocular microscope from the coarse-grained $(>0.02 \mathrm{~mm})$ residue obtained from $5 \mathrm{~g}$ of a sample. X-ray diffractometry (XRD) and element microanalysis were used as a control for chalcopyrite and pyrite. The same coarse-grained fractions of MBs were used for determining pyroclastic sanidine composition by XRD according to the method of Orville (1967), modified by applying contemporary computer facilities for curve fitting. The chemical composition of samples was determined by X-ray fluorescence, using pressed powder pellets for trace element analysis and fused with Li-tetraborate samples 1:5 for the study of main components. Host rock mineralogy in bulk rock was investigated by XRD.

\section{RESULTS}

\section{Chalcopyrite and $\mathrm{Cu}$ in terrigenous host rock}

The varicoloured terrigenous rocks investigated contained sparse chalcopyrite. Compared to the Viki core, the findings were more numerous in red beds of the Aizpute core. The grey interbeds alternating with red ones usually contained no chalcopyrite. The only exceptions were two samples from the Telychian and one from the Rhuddanian part in the Aizpute core, whereas the greenish-grey sample A962.75 was rich in chalcopyrite (Fig. 2). Some chalcopyrite was found also in yellow interlayers in the Viki and Nässumaa cores.

The average $\mathrm{Cu}$ content in red rocks was $23 \mathrm{ppm}$ and in the greenish-grey interlayers $46 \mathrm{ppm}$ (Table 2). Probably $\mathrm{Cu}$ in these rocks is bound into visually detectable chalcopyrite crystals. In dark grey rocks the $\mathrm{Cu}$ content was $60 \mathrm{ppm}$. For comparison, in Aeronian black shale from the Aizpute core, the $\mathrm{Cu}$ content averaged $100 \mathrm{ppm}$.

\section{Chalcopyrite and $\mathrm{Cu}$ in metabentonites}

All red MB samples contained chalcopyrite crystals. By correlating MB beds in different West Estonian cores (Kiipli et al. in press) the lateral distribution of chalcopyrite in some layers could be traced. The content of chalcopyrite in grey MBs of the Viki core was high at depths of 145.7 and $147.5 \mathrm{~m}$, decreasing in the corresponding layers of the shoreward Nässumaa, Lõetsa, and Kirikuküla cores (Fig. 3). 
Table 2. $\mathrm{Cu}$ contents in terrigenous and metabentonite samples, ppm

\begin{tabular}{l|c|c|c|c|c}
\hline & Minimum & Maximum & Average & $n$ & SD \\
\hline Terrigenous claystones of Aizpute and West Estonia & & & & \\
red & $<15$ & 40 & 23 & 11 & 7 \\
greenish-grey & $<15$ & 170 & 46 & 10 & 51 \\
dark grey & 20 & 90 & 60 & 6 & 23 \\
black shale* & 80 & 150 & 104 & 6 & 33 \\
& & & & & \\
Metabentonites of West Estonia & $<15$ & 120 & 43 & 14 & 30 \\
red & $<15$ & 220 & 48 & 13 & 57 \\
grey & $<$ & & & & \\
\hline
\end{tabular}

$\mathrm{Cu}$ content in metabentonites of Aizpute

$\begin{array}{lr}\text { red A953.99 } & 3000 \\ \text { red+grey A957.1 } & 640 \\ \text { red A957.75 } & 500 \\ \text { violet grey A964.4 } & 57\end{array}$

Detection limit of $\mathrm{Cu} 15 \mathrm{ppm} . n$, number of samples; * only the Aizpute core; SD, standard deviation.

The lateral change of the colour of the chalcopyrite-containing MB layer could also be followed. In two correlated MB layers colour changed from red in western cores to grey or white in eastern cores (red Pahapilli $64.6 \mathrm{~m}$ and grey Lõetsa $57.7 \mathrm{~m}$; red Viki $182.3 \mathrm{~m}$ and grey Pahapilli $72.2 \mathrm{~m}$ ) (Fig. 3), but no change in the amount of chalcopyrite was observed. The average $\mathrm{Cu}$ content was $43 \mathrm{ppm}$ in red MBs and $48 \mathrm{ppm}$ in grey MBs of West Estonia (Table 2).

The rather thin (from some $\mathrm{mm}$ to $1 \mathrm{~cm}$ ) MBs of the Aizpute core showed a higher concentration of chalcopyrite. The maximum $\mathrm{Cu}$ content reached $0.3 \%$ (Table 2). Greenish-grey or grey host rock contained sometimes layered MBs with the red upper part and the grey lower part (Viki 174.4-174.43 m, Pahapilli 65.65-65.7 m, Valjala 153.4-153.43 m, and Aizpute $957.1 \mathrm{~m}$ ). Chalcopyrite finds were more abundant in the upper red zone of MB.

Bleached haloes surrounding chalcopyrite crystals were recorded in some hematitic MB layers (Photo 1a). One sample (Photo 1c) contained many grey spots up to $1 \mathrm{~mm}$ in diameter, occurring as bleached greenish-grey areas in red hematitic matrix, surrounding biotite flakes, or having no cores. 


\section{Mineralogy of chalcopyrite-bearing host rock}

\section{Terrigenous rocks}

In the Aizpute core the terrigenous host rock is claystone, composed of illite, quartz, chlorite, dolomite, K-feldspar, and hematite and goethite as the colouring pigment in red rocks. The content of dolomite is about $5 \%$. The content of carbonate minerals increases shoreward. In Saaremaa, the investigated Velise Formation of the Viki core consists mainly of claystones with the about $10 \%$ content of carbonate minerals, which increases upwards to $20 \%$. The Nässumaa core section is represented by limestones and marls. The content of hematite plus goethite in red rock varieties is $2-3 \%$; the content of goethite in yellow rock varieties which are characteristic of Saaremaa sections may reach $12 \%$ (Kiipli et al. 2000).

\section{Metabentonite host}

In the Aizpute core chalcopyrite-rich MB layers consist of kaolinite and illitesmectite with hematite. The $1 \mathrm{~cm}$ thick MB A957.1 from the Aizpute core has three layers of different composition (Fig. 4). The grey layer is represented mainly by kaolinite with some illite-smectite, the greenish-grey one mainly by illite-smectite with kaolinite, and the red one by illite-smectite, kaolinite, and

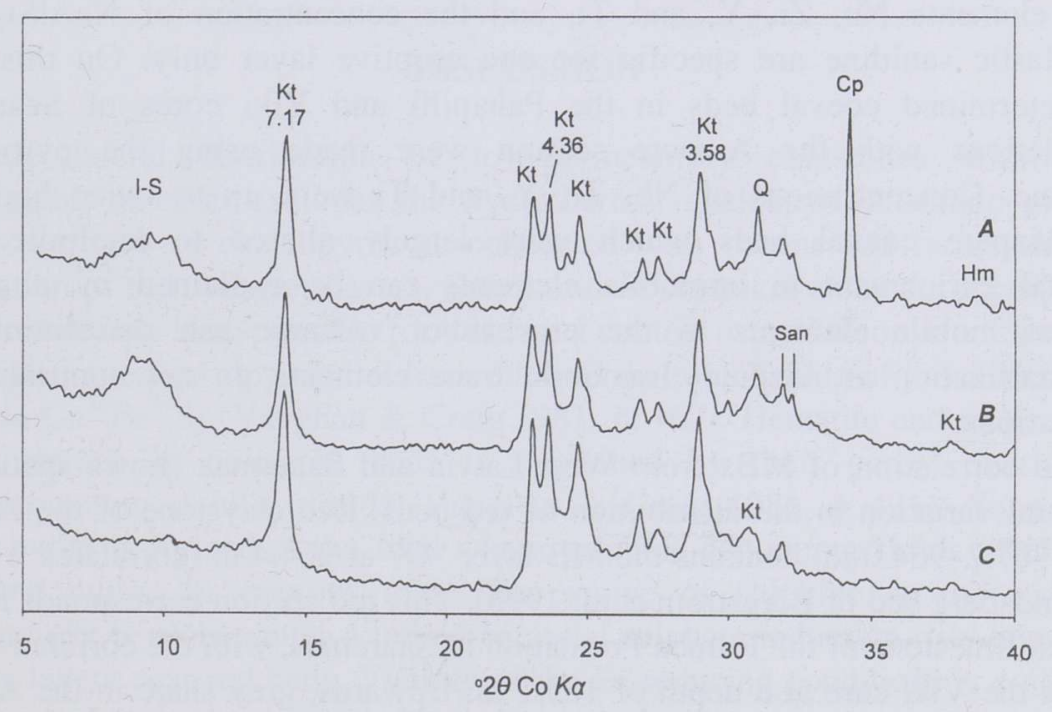

Fig. 4. X-ray diffractograms of metabentonite sample A957.1. Zones: A, red; B, green; C, grey. Abbreviations: I-S, illite-smectite; Kt, kaolinite; Q, quartz; San, sanidine; Cp, chalcopyrite; $\mathrm{Hm}$, hematite. Some selected $d$-values in $\AA$ are added to mineralogical indexes. 
hematite. Most Aizpute MBs from different Silurian stratigraphic levels contain kaolinite. The MBs from Saaremaa consist mainly of illite-smectite with authigenic K-feldspar. The content of hematite in red Aizpute samples was 3-6\%, in the Viki core samples on average $2 \%$. No goethite was recorded in red MB (Kiipli et al. 2000).

\section{Co-occurrences of pyrite and chalcopyrite}

Pyrite occurred together with chalcopyrite in grey MBs, in three grey and three red terrigenous samples. In some red terrigenous samples only pyrite was found. The content of pyrite was higher or equal to that of chalcopyrite when both minerals were present. Pyrite occurred mainly as framboids and aggregates of different size, mostly $<0.1 \mathrm{~mm}$. In one case the XRD study of the coarse $(>0.04 \mathrm{~mm}$ ) fraction of red $\mathrm{MB}$ (sample A953.99) revealed pyrite together with chalcopyrite.

\section{Correlation of sections}

In Table 1 the data of geochemical and mineralogical investigations of correlated $\mathrm{MBs}$ are presented. Stable concentrations and ratios of immobile trace elements $\mathrm{Nb}, \mathrm{Zr}, \mathrm{Y}$, and $\mathrm{Ti}$, and the concentration of $\mathrm{NaAlSi}_{3} \mathrm{O}_{8}$ in pyroclastic sanidine are specific for one eruptive layer only. On this basis we determined coeval beds in the Pahapilli and Viki cores of Saaremaa. Correlations with the Aizpute section were made using the pyroclastic sanidine. Concentrations of $\mathrm{Nb}, \mathrm{Zr}, \mathrm{Y}$, and $\mathrm{Ti}$ were up to twice higher in the Aizpute coeval beds which were largely altered to kaolinite. This residual enrichment in immobile elements can be explained by a greater loss of mobile elements in the process of volcanic ash dissolution and recrystallization at Aizpute. Immobile trace elements do not contradict the correlations.

The correlation of MBs from West Latvia and Saaremaa shows spatial and temporal variation in the distribution of red beds. Red claystone of the Aizpute core (967.7-964.0 m) contains the MB layer "O" at $964.4 \mathrm{~m}$ (correlates with the Osmundsberg bed of Bergström et al. 1998). This red section corresponds to grey nodular limestone of the Rumba Formation in Saaremaa, with the correlative "O" $\mathrm{MB}$ in the Viki core at a depth of $185.1 \mathrm{~m}$. Upwards, grey shale in the Aizpute core $(964-958 \mathrm{~m})$ correlates with the red section in the Viki core (183-176 m) (Fig. 5). Correlation of the MB layers from Aizpute and Saaremaa (Table 1; Fig. 5) shows that the correlative sections are 1.6 and 2 times thinner in the Aizpute core. This may hint at different sedimentation rates in shoreward and offshore deep shelf areas. 


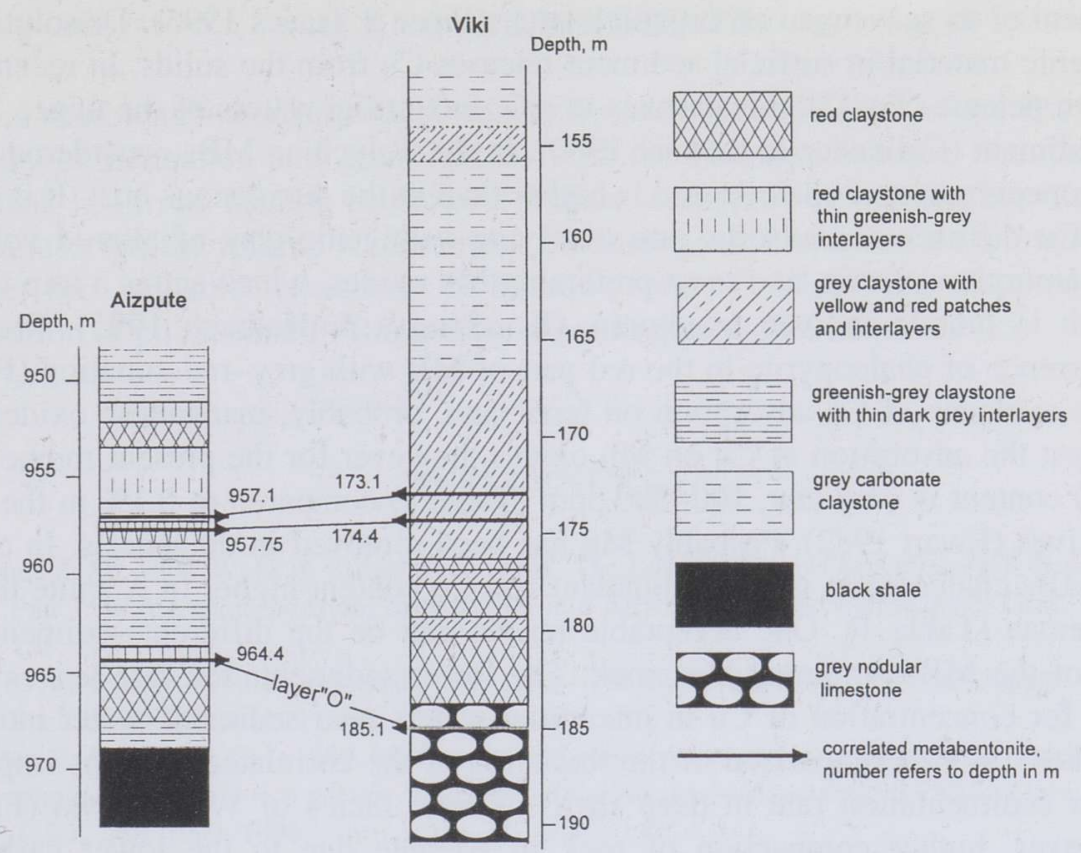

Fig. 5. Correlation of three metabentonite layers of the Aizpute and Viki cores.

\section{DISCUSSION}

Wide lateral distribution of low-permeability claystones within one stratigraphic interval excludes the hydrothermal chalcopyrite-forming process. The occurrence of chalcopyrite is connected with marine red facies showing alternation of red and grey layers. Speciation of chemical elements according to redox conditions is responsible for this facial control over chalcopyrite formation. Mössbauer spectroscopy studies have allowed the establishing of the chalcopyrite formula $\mathrm{Cu}^{1+} \mathrm{Fe}^{3+} \mathrm{S}_{2}$ (Vaughan \& Craig 1981, p. 167). Hematite and chalcopyrite co-occurrence in oxic red beds is explained by their partly overlapping thermodynamic stability fields (Vaughan \& Craig 1981, p. 431). Supposedly chalcopyrite is formed at the sites where sulphide-containing fluids meet ferric iron and cupric or cuprous ions. The source of sulphide in the red oxic environment is problematic. Limited bacterial sulphate reduction may take place in grey layers near red beds. Vicinity of the Fe-reducing conditions is evidenced by bleached haloes around chalcopyrite crystals or rare grey spots within red matrix. Substitution of grey colour for red in shoreward direction is observed in some chalcopyrite-containing coeval MB layers. Most of the chalcopyrite finds come from MBs. Nevertheless, chalcopyrite is an authigenic, not effusive mineral, as it occurs both in volcanic and terrigenous host rock. Probably $\mathrm{Cu}$ is transported and deposited to the sediment in the biogenic phase as a biologic 
element or as scavenged on organic matter (Piper \& Isaacs 1995). Dissolution of biogenic material in surficial sediment releases $\mathrm{Cu}$ from the solids. In recent redbrown pelagic clay $\mathrm{Cu}$ concentrates in oxic interstitial waters of the upper $10 \mathrm{~cm}$ of sediment (Callender \& Bowser 1980). In the Telychian MBs considered by us the concentration of chalcopyrite is higher than in the terrigenous host. It is likely that $\mathrm{Cu}$ diffuses and adsorbs into overlying authigenic clay of altered volcanic ash, amorphous ferric, and most preferably $\mathrm{Mn}$ oxides, which act as a trap for $\mathrm{Cu}$ which is mobile in oxic conditions (Koschinsky \& Halbach 1995). Frequent occurrence of chalcopyrite in the red part of MB with grey-red zonation (Fig. 4) gives evidence of $\mathrm{Cu}$ adsorption on ferric and, probably, manganese oxides. We suggest the adsorption of $\mathrm{Cu}$ on $\mathrm{Mn}$ oxides, however for the present moment the $\mathrm{MnO}$ content is very low, $100-300 \mathrm{ppm}$ (Table 1) compared to $0.1 \%$ in the fresh effusives (Ewart 1983). Probably Mn has been removed in diagenesis. In coeval red MBs chalcopyrite is more abundant and $\mathrm{Cu}$ content higher in Aizpute than in Saaremaa (Table 1). One acceptable reason can be the different sedimentation rate of the MB-containing host rock. The lower sedimentation rate leaves more time for concentration of $\mathrm{Cu}$ in interstitial waters near sediment-water interface (Volkov 1979). Comparison of the thickness of the correlated sections implies a lower sedimentation rate in deep shelf offshore facies of West Latvia (Fig. 5). However, higher compaction of rock in Aizpute due to the lower carbonate content (5\% in the Aizpute core, $10 \%$ in the Viki core) and greater depth of bedding can distort the results of the comparison of initial sedimentation rates. Nevertheless, the sedimentation rate can have some influence on the amount of chalcopyrite. The other reason for higher $\mathrm{Cu}$ concentration in Aizpute MBs may be connected with the mechanism of enrichment which took place after $\mathrm{Cu}$ adsorption in MB. Removal of mobile elements, mainly silica, causes an increase in the concentration of $\mathrm{Cu}$ and immobile elements of volcanic origin $-\mathrm{Nb}, \mathrm{Zr}, \mathrm{Y}$, and $\mathrm{Ti}$. This explains also the positive correlation between increased contents of $\mathrm{Cu}$ and named elements in Aizpute MBs (Table 1).

\section{CONCLUSIONS}

The studied chalcopyrite is early diagenetic and its distribution is subjected to sedimentary facies control. A higher concentration of chalcopyrite in MBs compared to terrigenous rock is caused by better $\mathrm{Cu}$-adsorbing properties of fresh altered volcanic ash material. In the Aizpute core chalcopyrite is more numerous, in MBs as well as in terrigenous rocks, than in Saaremaa cores. The lateral variation in the amount of chalcopyrite and $\mathrm{Cu}$ content within the correlated $\mathrm{MB}$ layer depends on the redox conditions of chalcopyrite formation sites and conditions for $\mathrm{Cu}$ concentration in the layer near the sediment-water interface prior to volcanic ash deposition. Based on the correlation of three MB layers, the earlier onset of Telychian red facies in the Aizpute region compared to Saaremaa can be concluded. 


\section{ACKNOWLEDGEMENTS}

This work was financially supported by Project No. 0140226B of the Estonian Ministry of Education and grant No. 4070 of the Estonian Science Foundation. We thank E. Pirrus, Mining Institute of Tallinn Technical University, for reading the manuscript, the referee K. Kirsimäe, University of Tartu, and an anonymous referee for valuable criticism. G. Baranov and O. Hints are thanked for preparation of photos and $\mathrm{P}$. Rummi for providing us with a fusion device.

\section{REFERENCES}

Bergström, S. M., Huff, W. D. \& Kolata, D. R. 1998. The Lower Silurian Osmundsberg K-bentonite. Part I: stratigraphic position, distribution, and palaeogeographic significance. Geol. Mag., 135, 1-13.

Boyle, E. A., Sclater, F. R. \& Edmond, J. M. 1977. The distribution of dissolved copper in the Pacific. Earth Planet. Sci. Lett., 37, 38-54.

Callender, E. \& Bowser, C. J. 1980. Manganese and copper geochemistry of interstitial fluids from manganese nodule-rich pelagic sediments of the Northeastern equatorial Pacific Ocean. Am. J. Sci., 280, 1063-1096.

Chester, R., Thomas, A., Lin, F. J., Basaham, A. S. \& Jacinto, G. 1988. The solid state speciation of copper in surface water particulates and oceanic sediments. Mar. Chem., 24, 261-292.

Dubinin, A. V. 1998. Fe-Mn crust on pelagic sediments: geochemistry and genesis. Geokhimiya, 11, 1152-1163 (in Russian).

Ewart, A. 1983. Mineralogy and chemistry of Tertiary and recent dacitic, latitic, rhyolitic and related salic volcanites. In Trondhjemites, Dacites and Related Rocks (Barker, F., ed.), pp. 19-98. Mir, Moscow (in Russian).

Gustafson, L. B. \& Williams, N. 1981. Sediment-hosted stratiform deposits of copper, lead and zinc. Econ. Geol., 75, 139-178.

Hofmann, B. A. 1991. Mineralogy and geochemistry of reduction spheroids in red beds. Mineral. Petrol., 44, 107-124.

Jeppsson, L. \& Männik, P. 1993. High-resolution correlations between Gotland and Estonia near the base of the Wenlock. Terra Nova, 5, 348-358.

Jimenez-Espinoza, R., Jimenez-Millan, J. \& Nieto, L. 1997. Factors controlling the diagenesis of the Fe-Mn crusts in stratigraphic breaks of the eastern Betic Cordillera (SE Spain) deduced from numerical analysis of geological data. Sedim. Geol., 114, 97-107.

Kaljo, D. 1977. Structural and facial subdivisions on the East Baltic Silurian basin. In Facies and Fauna of the Baltic Silurian (Kaljo, D., ed.), pp. 6-13. Acad. Sci. Estonian SSR, Tallinn (in Russian).

Kiipli, E., Kallaste, T. \& Kiipli, T. 2000. Hematite and goethite in Telychian marine red beds of the East Baltic. GFF, 122, 281-286.

Kiipli, T., Männik, P., Bachelor, R., Kiipli, E., Kallaste, T. \& Perens, H. Correlation of Telychian (Silurian) metabentonites in the Baltic region. Norsk Geol. Tidskr. (in press).

Koschinsky, A. \& Halbach, P. 1995. Sequential leaching of marine ferromanganese precipitates: genetic implications. Geochim. Cosmochim. Acta, 59, 5113-5132.

Kuuspalu, T. \& Vanamb, V. 1975. Metalliferous mineralization in gravel from Laeva quarry. Acta Comment. Univ. Tartuensis, 359, 142-151 (in Russian).

Nestor, H. 1997. Silurian. In Geology and Mineral Resources of Estonia (Raukas, A. \& Teedumäe, A., eds.), pp. 85-106. Estonian Acad. Publ., Tallinn. 
Novikov, G. V. \& Skornyakova, N. S. 1998. Adsorption properties of oceanic Fe-Mn concretions and crusts. Geokhimiya, 5, 505-517 (in Russian).

Orville, P. M. 1967. Unit-cell parameters of the microcline-low albite and the sanidine-high albite solid solution series. Am. Mineral., 52, 55-86.

Piper, D. Z. \& Isaacs, C. M. 1995. Geochemistry of minor elements in the Monterey Formation, California: seawater chemistry of deposition. U.S. Geol. Surv. Prof. Pap., 1566.

Pirrus, E. 1962. Omapärasest kalkopüriidi leiust Eestis. Eesti Loodus, 2, 99-101.

Pirrus, E. 1973. Vaseühend fosfaatveerises. Eesti Loodus, 9, 541-542.

Rose, A. W. 1976. The effect of cuprous chloride complexes in the origin of red-bed copper and related deposits. Econ. Geol., 71, 1036-1048.

Vaughan, D. J. \& Craig, J. R. 1981. Khimiya sulfidnykh mineralov. Mir, Moscow (in Russian). (Translated from Mineral Chemistry of Metal Sulfides, 1978, Cambridge Univ. Pr.)

Volkov, I. I. 1979. Redox processes in sediment diagenesis. In Khimiya okeana, vol. 2, Geokhimiya donnykh osadkov (Volkov, I. I., ed.), pp. 363-413. Nauka, Moscow (in Russian).

\title{
VARADIAGENEETILISE KALKOPÜRIIDI ILMINGUD TELYCHI MERELISTES PUNAVÄRVILISTES KIVIMITES LÄÄNE-EESTIS JA LÄÄNE-LÄTIS
}

\author{
Enli KIIPLI, Tarmo KIIPLI ja Toivo KALLASTE
}

Saaremaa ja Aizpute puursüdamike alamsiluri Telychi-ealistest punavärvilistest kivimitest leiti kuni 0,5 mm läbimõõduga kalkopüriidi kristalle. Kalkopüriit on tekkelt varadiageneetiline, sest see on levinud laialdasel maa-alal ja on seotud kindla faatsiesega - punavärviliste savikivimitega, milles esineb rohekashalle vahekihte. Leide on hulgalisemalt punavärvilistes metabentoniidi vahekihtides, vähem terrigeenses kivimis. Kristallide metabentoniitidesse kontsentreerumise põhjuseks on ilmselt vulkaanilisest tuhast moodustunud autigeense savi ning amorfse raua oksiidide ja oletatavate, praeguseks mitte säilinud mangaanioksiidide head vaske adsorbeerivad omadused. Aizpute puursüdamikus on leiud Saaremaa läbilõigetega võrreldes arvukamad.

Aizpute ja Viki puuraugu kolme metabentoniidikihi korreleerimise põhjal võib väita, et Telychi punavärviline faatsies on Aizputes varasem kui Saaremaal.

\section{РАННЕДИАГЕНЕТИЧЕСКИЙ ХАЛЬКОПИРИТ В ТЕЛИЧИАНСКИХ МОРСКИХ КРАСНОЦВЕТНЫХ ПОРОДАХ ЗАПАДНОЙ ЭСТОНИИ И ЗАПАДНОЙ ЛАТВИИ}

\author{
Энли КИЙПЛИ, Тармо КИЙПЛИ и Тойво КАЛЛАСТЕ
}

Найдены кристаллы халькопирита диаметром до 0,5 мм в раннесилурийских красноцветных породах скважин о-ва Сааремаа (Западная Эстония) и скв. Айзпуте (Западная Латвия). Эти кристаллы распростра- 
нены в красноцветных с зеленовато-серыми прослоями глинах. Находки более многочисленны в метабентонитовых прослоях, чем в терригенной породе. Причиной является, видимо, хорошая медь-адсорбируюшая способность аутигенной глины, а также аморфных оксидов железа и марганца. Оксиды марганца в диагенезе не сохранились. Халькопирит чаще встречается в красноцветах скв. Айзпуте и реже в породах сааремааских скважин. Корреляция трех метабентонитовых прослоев между скв. Айзпуте и Вики указывает на более ранний диагенез теличианской красноцветной фации в Айзпуте по сравнению с таковой на о-ве Сааремаа. 